A.P. Voinov, Dr.Eng., Professor,

A.S. Mazurenko, Dr.Eng., Professor,

E.K. Olesevich, Ph.D., Assoc.Prof.,

Odessa National Polytechnic University

\title{
PREDICTIVE ASSESSMENT OF THE UKRAINIAN POWER INDUSTRY FUEL BALANCE STRUCTURE PROGRESS
}

Introduction. The current structure of the fuel and energy balance in power engineering sector of Ukraine causes unreasonably high price of electricity and heat as this industry products. That situation is due to the essential share (about $40 \%$ ) of highly expensive imported gaseous and liquid fuels in the national fuel balance structure.

Analysis of recent research and publications. The industry fuel base regulation the can be achieved by avoiding expensive import and the transition to low-cost domestic energy fuels $[1,2]$.

This task does require the implementation of scientific and technical-organizational cross-sectoral program of the state-level complexity and importance. To solve the problem, various approaches can be applied with subsequent possible result assessment.

Aim of Research. Analyze the main possible directions to normalize the fuel and energy balance of Ukraine.

Main Body.

Approach A. The most natural approach is to displace (replace) the expensive imported gas and oil fuel with the domestic solid fuel by converting part of boilers fueled by natural gas or fuel oil, into these operating with solid fuel.

This solution is, a-propos, a highly effective one. However, its implementation shall require the technical upgrade and modernization of allocated boiler installations, as well as re-equipment and modernization of power plants industrial sites' infrastructure. Such upgrading program reveals a need in essential capital investments.

Under these circumstances, the only reasoned way seems to be in creation and introduction into national industry practice new type of station-installed and industrial boiler plants equipped with furnaces for burning solid fuel. At the same time, it would be most appropriate to use at most of them an innovative burning-boiler technology of low-temperature fluidized bed, which allows highly efficient use of low-grade solid fuel. And only some of the new small boilers located in small towns will be advisable to equip with the gas-fuel oil furnaces [3].

Approach B. Displacement (replacement) of the expensive foreign gas and fuel oil with the domestic non-expensive gaseous fuels. This approach can be implemented in various ways, depending on the category (source) of gas fuel used (replacing alternative).

Path B1. Displacing the expensive imported gas with the domestic non-expensive natural gas. This path almost does not require any investments from the boiler owner's side, at the installation continue to burn fuel of the same grade that project design supposed. However, the natural gas represents a non-renewable and irreplaceable raw material for a number of industries, whose need in gas is rapidly increasing. Considering that fact, as well as small domestic resources of natural gas, focusing on its long-term use in power industry fuel, would be impractical. Therefore the B1 path should be used only temporarily.

Path B2. Displacement of the expensive gas-fuel oil with the domestic inexpensive gas obtained at solid fuel pyrolysis. The theoretical and practical research on its industrial production issues are car-

DOI 10.15276/opu.2.44.2014.19

(C) A.P. Voinov, A.S. Mazurenko, E.K. Olesevich, 2014

ЕНЕРГЕТИКА. ТЕПЛОТЕХНІКА. ЕЛЕКТРОТЕХНІКА 
ried at the Ukraine National Academy of Science [4]. A proper development of pyrolysis gas industrial production can result in not only regional but also national-scale significance of such fuel application.

Path B3. Displacement of imported gas and fuel oil with the domestic low-cost shale gas (ShG). This way in recent years is attracting more and more attention. Its main features relate to the ShG use in the domestic power engineering sector that we shall try to describe briefly.

The ShG is a non-renewable fuel, non-conventional for Ukraine. Several countries are developing ShG mining. The term "unconventional" herein is primarily due to the peculiarities of its production technology. The domestic energy industry has no experience in this fuel use. However, taking into account the foreign countries' (particularly the United States') experience, this fuel can be considered of practical interest under present highly complicated situation of national power engineering industry fuel balance structure reviewing [5]. The main advantages and disadvantages of ShG are well-known [6].

At the governmental level, a decision has been made to start the proven ShG fields development in Ukraine. The two shale deposits' mining areas works are initiated in the western and eastern regions of the country. Estimate date of marketable ShG commercial production start refer to 2019...2020.

Indeed the in-depth research, analysis and objective evaluation from different perspectives should include all aspects of ShG production, transportation and use in the specific conditions of those regions, where this fuel type is expected to be used.

Several sources indicate that the conversion of a boiler plant operating on natural gas, into ShGfuel is not limited to the simple boiler fuel receiving tube switching from one gas manifold to another. In fact, after such switching onto ShG mains, the boiler plant may become inoperative. The sources state that the failure may be due to the difference in combustion heat, this value for ShG being, lower than the natural gas' calorific value. They argue with the value of $14,50 \ldots 15,10 \mathrm{MJ} / \mathrm{m}^{3}\left(3460 \ldots 3600 \mathrm{kcal} / \mathrm{m}^{3}\right)$, from which conclusions are drawn about the impossibility to use the existing natural gas pipelines' full capacity to transport the shale gas. Thus they suggest a substantiation of necessity to develop special type of ShG burners, different from the traditional gas turbines' burners. To our opinion, such objectivation does need for a critical look at the background study.

Supposingly, it can be assumed that the allegations of ShG low calorific value are based on the substitution of the natural shale gas properties with similar characteristics of artificial shale gas, produced at the gasification of oil shale [7]. So, the syngas' calorific value equal to $12,6 \ldots 14,3 \mathrm{MJ} / \mathrm{m}^{3}$ $\left(3000 \ldots 3400 \mathrm{kcal} / \mathrm{m}^{3}\right)$ is attributed by analogy to the natural shale gas.

In addition, the performed research, investigation and critical analysis of the collected data allow us to consider the data as quoted above on natural ShG low combustion heat uncharacteristic ones eventually relating to certain abnormal conditions of that gas recovery.

In such a way we faced a need to collect, analyze and discuss the available information on the ShG composition and properties.

Here below we used the officially published data of companies that have the greatest experience in ShG production, transportation and use. The results obtained suggest, in general, that the ShG as an energy industry fuel is close by its combustion heat to the natural gas.

The most important data on the characteristics of ShG recovered at several accumulation fields in USA are summarized in Table [8]. The tabulated data analysis shows that:

- It should be noted that the chemical composition values shown in the table for six USA shale deposits have been obtained as the arithmetic mean of a limited wells' number (four wells) [9]. This may call into question the reliability of the calculated calorific values' correspondence to the real average values over the entire volume of gas for each field;

- Evaluating the average value of the shale gas specific net calorific value for the considered deposits in USA, it is expedient to take into account the deposit resources' volume, i.e. to determine the combustion heat for those resources' weighted average volumetric value. These data preliminary analysis reveals insignificant amounts of shale gas in deposit fields having anomalistic chemical composition: Antrim, Bakken and Utica therefore, these fields' data have been excluded from the further analysis. 
Heat of combustion, and the main USA shale gas deposits' resource [8]

\begin{tabular}{|c|c|c|c|c|c|c|c|c|c|}
\hline \multirow{2}{*}{ Shale Plays } & \multicolumn{7}{|c|}{ Chemical composition, $\%$} & \multirow{2}{*}{$\begin{array}{c}Q, \\
\mathrm{kcal} / \mathrm{m}^{3}\end{array}$} & \multirow{2}{*}{$\begin{array}{l}\text { Resource, } \\
\text { trillions } \mathrm{m}^{3}\end{array}$} \\
\hline & $\mathrm{CH}_{4}$ & $\mathrm{C}_{2} \mathrm{H}_{6}$ & $\mathrm{C}_{3} \mathrm{H}_{8}$ & $\mathrm{CO}_{2}$ & $\mathrm{~N}_{2}$ & Oil & $\mathrm{CO}_{2}+\mathrm{N}_{2}$ & & \\
\hline Fayettevill & 97 & 1 & 0 & 1 & 1 & 0 & 2 & 8485 & 0,906 \\
\hline Woodford & 96 & 1 & 0 & 3 & 1 & 0 & 4 & 8368 & 0,623 \\
\hline Haynesville & 95 & 0 & 0 & 5 & 0 & 0 & 5 & 8130 & 2,124 \\
\hline New Albany & 90 & 1 & 1 & 8 & 0 & 0 & 8 & 8073 & 0,312 \\
\hline Cana Woodford & 88 & 5 & 2 & 0 & 0 & 0 & 0 & 8729 & 0,170 \\
\hline Devonian & 88 & 5 & 2 & 0 & 3 & 0 & 3 & 8729 & 0,821 \\
\hline Barnett & 85 & 7 & 2 & 2 & 3 & 0 & 5 & 8776 & 1,218 \\
\hline Marcellus & 81 & 18 & 1 & 0 & 0 & 0 & 0 & 9891 & 11,610 \\
\hline Eagle Ford & 75 & 14 & 5 & 2 & 0 & 0 & 2 & 9641 & 0,595 \\
\hline Utica & 69 & 6 & 3 & 0 & 0 & 21 & 0 & 9468 & 1,076 \\
\hline Antrim & 62 & 4 & 1 & 4 & 29 & 0 & 33 & 6133 & 0,566 \\
\hline Bakken & 31 & 2 & 1 & 0 & 0 & 65 & 0 & 9351 & 0,283 \\
\hline \multicolumn{9}{|l|}{ TOTAL } & 20,303 \\
\hline
\end{tabular}

As a result, we obtained the weighted average calorific value on nine shale gas deposits in USA $37,17 \mathrm{MJ} / \mathrm{m}^{3}\left(8872 \mathrm{kcal} / \mathrm{m}^{3}\right)$. In this regard, every reference to a low calorific value of shale gas $15,08 \mathrm{MJ} / \mathrm{m}^{3}\left(3600 \mathrm{Kcal} / \mathrm{m}^{3}\right)$ either values close to that, requires a well-reasoned and thorough study.

According to the chemical analysis implemented for the nine most characteristic fields in USA (refer to Table.), the ShG basically consists of methane $\left(\mathrm{CH}_{4}\right)$, which content ranges from 75 to $97 \%$, and ethane $\left(\mathrm{C}_{2} \mathrm{H}_{6}\right)$ varying from 0 to $18 \%$, the summarized contents in nitrogen $\left(\mathrm{N}_{2}\right)$ and carbon dioxide $\left(\mathrm{CO}_{2}\right)$ can reach the level up to $8 \%$. In USA, the standard (natural) gas calorific value is taken to be $38,59 \mathrm{MJ} / \mathrm{m}^{3}\left(9211 \mathrm{kcal} / \mathrm{m}^{3}\right)$. The tested ShG samples' calorific value ranged from $28,46 \ldots 35,80 \mathrm{MJ} / \mathrm{m}^{3}$ $\left(6793 \ldots 8543 \mathrm{kcal} / \mathrm{m}^{3}\right)$ to $41,01 \ldots 45,17 \mathrm{MJ} / \mathrm{m}^{3}\left(9789 \ldots 10780 \mathrm{kcal} / \mathrm{m}^{3}\right)$; i.e. a deviation from the standard, has been within limits from $-26 \%$ to $+17 \%$. That is, the range of American ShG combustion heat fluctuation is large, about $43 \%$. It is possible that the instability of this main ShG characteristic in Ukraine may be greater than in the USA.

Given that circumstance, it is necessary, prior to switching a boiler plant to ShG operation, to reconstruct its fuel system, burners, draft facilities, reconfiguring also the automatic control system. Consequently, required is to carry out the boiler plant commissioning, testing etc. As a result, the boiler system will become ready to ShG combustion. At the same time, its technical characteristics and technological efficiency performance (both environmental and economic ones) will also undergo changes, depending on the negative impact of various interrelated factors' series.

An independent part of the overall problem of using the ShG as a fuel for domestic energy industry is the task of converting into ShG-consuming the natural gas turbine and diesel electrical power generating plants as well as gas turbines representing components of combined-cycle thermal power plants.

In this relatively new field the transition to ShG also raises a number of complicated scientific and technical problems still the national power generation industry has not yet accumulated experience in dealing with.

Another independent part of the ShG using problem relates to the problem of its transportation from gas recovery areas to consumers.

Both natural and attractive is the idea of using a part of the existing gas supply system, now delivering the natural gas, for ShG transportation.

For that reason it is necessary to study the feasibility of ShG use for the existing gas compressor units with gas turbine drive, designed for natural gas burning and located on the main gas pipelines.

Results. The task of ShG recovery is fairly related to the problem of efficient gas transportation systems creation. These two aspects together with the above exposed problem of boiler plants, gas turbines and reciprocating engines conversion to ShG represent the basis of the generalizing problem in ShG use for the national power generation industry needs. 
There are some reasons to believe that in the future it would be appropriate to use the liquefied shale gas at low capacity power plants, now operating with gaseous and liquid fuels.

In general, the conception of using the $\mathrm{ShG}$ as a fuel for the national power generating industry requires to solve preliminary a complex of scientific and technical-organizational tasks, in particular:

- Further development of scientific and technological research in the ShG applicability field for the station-installed and industrial heating boiler and combusting systems, as well as for gas turbines, reciprocating generators etc;

- The development of ShG transportation systems.

In solving the problem of the national power industry fuel balance structure normalization the approach $\mathbf{A}$ allocates an important role to the design and engineering development of special (including standard ones) solutions to convert the gas-oil boiler systems onto solid fuels burning. It is advisable that these works of high priority were carried out ahead of the works related to the approach B.

It seems appropriate to begin the implementation of the above tasks (both cases of A and B approaches), with the renewal of equipment facilities, operated the greatest period of time.

In general, the order of implementing the A and B approaches as well as B approach components should be established taking into account the complex conditions prevailing in each region of the country.

The upcoming ShG use at the Ukrainian power generating industry can significantly change the configuration of views, positions and all sorts of decisions taken in the field of the governmental fuel policy.

Especially important is to take into account that, according to international experience, the used ShG mining technology does bear a high level of environmentally adverse effects' risk. In this regard, the program of ShG production and use in Ukraine should contain adequate protective measures and norms limiting those harmful effects.

\section{Conclusions:}

- The Ukrainian power generating industry fuel-and-energy balance now has an extremely unfavorable structure. The problem of its normalization acquires a top priority among state-level importance issues. The main objective herein is to reduce the imported gas fuel oil share in the fuel balance structure.

- A promising priority trend in development of domestic power industry fuel base consists in increasing the solid fuels share in the industry balance structure.

- An important program objective relates to the development and increase in the inexpensive domestic gas fuel mining and production.

- The investigation and arrangements to the development of shale gas deposits, implemented under the top governmental priority in the eastern and western regions of the country represent high necessity decision taken in due time.

- An important contribution to the development and improvement of the industry's fuel base is expected upon future development of the solid fuel pyrolysis gas production.

- In the foreseeable future a number of various complicated tasks are to be solved on the way to the shale gas highly efficient use on an industrial scale.

- Implementation of the shale gas production and use in the national economy program will require highly qualified personnel engaging, as well as large capital investments.

- The implementation of Ukrainian program on shale gas production and industrial use should contain every adequate measures and tools limiting the environmentally harmful effects of its production.

\section{Література}

1. Теплова енергетика - нові виклики часу: [техн. зб.] / за заг. ред. П. Омеляновського, Й. Мисака; [упоряд. А. Акімов]. — Львів: Українські технології, 2009. - 658 с.

2. Макогон, Ю.В. Инновации в сфере энергетики в старопромышленном регионе Украины / Ю.В. Макогон, А.Е. Анисимов // Мінер. ресурси України. - 2014. - № 1. - С. 28 - 35.

3. Воінов, О.П. Розвиток котлобудування — пріоритетне завдання енергетичного машинобудування України / О.П. Воінов // Новые и нетрадиционные технологии в ресурсо- и энергосбережении: 
материалы науч.-техн. конф., 19-22 сентября 2011 г., Одесса. - К.: АТМ Украины, 2011. C. $22-26$.

4. Корчевой, Ю.П. Нові технології використання вугілля в енергетиці / Ю.П. Корчевой, Г.Г. Півняк // Вісн. НАН України. - 2006. - № 2. - С. $51-58$.

5. Сланцевый газ - проблемы и перспективы добычи на Украине / В.Т. Кривошеев, В.Д. Кукуруза, Е.3. Иванова, В.В. Макогон // $11^{\text {th }}$ International Conference on Geoinformatics - Theoretical and Applied Aspects, 14-17 May 2012, Kiev, Ukraine. — Red Hook, NY: Curran Associates, Inc., 2012. PP. $117-122$.

6. Васильченко, А. Сланцевый газ в наших условиях - пузырь газа и много бед / Анатолий Васильченко // Зеркало недели. — № 19. - 31 мая 2013.

7. Стрижакова, Ю.А. Технология переработки горючих сланцев: этапы становления и перспективы развития / Ю.А. Стрижакова, Т.В. Усова, А.С. Малиновский // Изв. вузов. Химия и хим. технология. - 2007. - Т. 50, № 6. - С. $9-14$.

8. O хорошем и плохом газе [Електронний ресурс] / MIRVN: Мир вокруг нас. — 2014. — Режим доступу: http://mirvn.livejournal.com/10459.html (Дата звернення: 20.07.2014).

9. Bullin, K.A. Composition variety complicates processing plans for US shale gas / K.A. Bullin, P.E. Krouskop // Oil \& Gas Journal. — 2009. — Vol. 107, Issue 10. — PP. 50 — 55.

\section{References}

1. Omelyanovskiy, P. and Mysak, Y. (Eds.). (2009). Thermal energetics - new challenges of time. Lviv: Ukrainski tehnologii.

2. Makogon, Yu.V. and Anisimov, A.E. (2014). Energy innovations in old industrial region of Ukraine. Mineral Resources of Ukraine, 1, 28-35.

3. Voinov, O.P. (2011). Development of boiler industry is a priority task of the power machine building of Ukraine. In Proceedings of International Scientific and Technical Conference on New and Innovative Technologies in Resource and Energy Conservation (pp. 22-26). Kyiv: ATM Ukrainy.

4. Korchevoj, J.P. and Pivnyak, G.G. (2006). New coal technologies in energetics. Herald of the National Academy of Sciences of Ukraine, 2, 51-58.

5. Kryvoscheyev, V., Kukuruza, V., Ivanova, Y. and Makogon, V. (2012). Shale gas — problems and prospects of production in Ukraine. In Proceedings of $11^{\text {th }}$ International Conference on Geoinformatics - Theoretical and Applied Aspects (GeoInformatics 2012) (pp. 117-122). Red Hook, NY: Curran Associates, Inc.

6. Vasilchenko, A. (2013, May 31). Shale gas in our environment - a bubble of gas and a lot of troubles. Mirror Weekly. Retrieved from http://gazeta.zn.ua/energy_market/slancevyy-gaz-v-nashih-usloviyahpuzyr-gaza-i-mnogo-bed-_html

7. Strizhakova, Yu.A., Usova, T.V. and Malinovsky, A.S. (2007). The processing technology of combustible shale: stages of formation and development prospective. Izvestiya Vysshikh Uchebnykh Zavedenii: Khimiya i Khimicheskaya Tekhnologiya, 50(6), 9-14.

8. mikhail_t (2014). About good and bad gas [Web log post]. Retrieved from http://mirvn. livejournal.com/10459.html

9. Bullin, K.A. and Krouskop, P.E. (2009). Composition variety complicates processing plans for US shale gas. Oil \& Gas Journal, 107(10), 50-55.

\section{АНОТАЦІЯ / АННОТАЦИЯ / ABSTRACT}

О.П. Воінов, А.С. Мазуренко, С.К. Олесевич. Перспективи розвитку структури паливного балансу енергетики України. Структура паливного балансу України багато в чому визначає високі ціни виробленої в енергетиці продукції - електроенергії і теплоти. Основна причина полягає у тому, що приблизно 40 \% структури паливного балансу становить дороге імпортне рідке і газоподібне паливо. Безумовно, така структура балансу суттєво впливає на енергетичну безпеку України. У статті проаналізовано три основні можливі напрямки нормалізації вказаного положення: витіснення імпортного газу відносно недорогим вітчизняним вугіллям, яке спалюється в інноваційних котельно-топкових системах, насамперед, у котлах з топками низькотемпературного киплячого шару; заміна імпортного палива недорогим штучним газом піролізу вітчизняного низькосортного бурого вугілля; організація вітчизняного видобутку сланцевого газу, промисловий видобуток якого заплановано на 2020 рік. Наведені перспективні напрями розвитку структури паливного балансу енергетики України можуть розглядатися як пріоритетні частини загальнодержавного завдання підвищення енергетичної незалежності країни.

Ключові слова: паливний баланс, енергетика, рідке паливо, газоподібне паливо. 
А.П. Воинов, А.С. Мазуренко, Е.К. Олесевич. Перспективы развития структуры топливного баланса энергетики Украины. Сложившаяся структура топливного баланса Украины во многом определяет высокие цены производимой в энергетике продукции - электричества и теплоты. Основная причина состоит в том, что примерно 40 \% структуры топливного баланса составляет дорогое импортное жидкое и газообразное топливо. Безусловно, такая структура баланса существенно влияет на энергетическую безопасность Украины. В статье проанализированы три основные возможные направления нормализации указанного положения: вытеснение импортного газа относительно недорогим отечественным углем, сжигаемым в инновационных котельно-топочных системах, прежде всего в котлах с топками низкотемпературного кипящего слоя; замена импортного топлива недорогим искусственным газом пиролиза отечественных низкосортных бурых углей; организация добычи отечественного сланцевого газа, промышленная добыча которого намечена на 2020 год. Приведенные перспективные направления развития структуры топливного баланса энергетики Украины могут рассматриваться как приоритетные части общегосударственной задачи повышения энергетической независимости страны.

Ключевые слова: топливный баланс, энергетика, жидкое топливо, газообразное топливо.

A.P. Voinov, A.S. Mazurenko, E.K. Olesevich. Predictive assessment of the Ukrainian power industry fuel balance structure progress. The existing structure of the fuel balance in Ukraine does largely determine high prices of such energy products as the electricity and the heat. The main reason lies in the fact that approximately $40 \%$ of the fuel balance represents the expensive imported liquid and gaseous fuels. Of course, such balance structure significantly affects the energy security of Ukraine. The article analyzes the three main directions of this situation possible normalization: replacing the imported gas with relatively inexpensive domestic coal burned at boilers and innovative coal-fired burner systems, especially in the low-temperature boilers with fluidized bed furnaces; replacement of imported fuel with respectively cheap pyrolysis gas obtained from the domestic low-grade brown coal; organization of domestic production of shale gas, which industrial production is scheduled for 2020. These promising directions of the national energetics' fuel balance development can be considered as a priority part of the national tasks of increasing the country's energy independence.

Keywords: fuel balance, power engineering, liquid fuel, gaseous fuel.

Reviewer Dr. techn. sciences, Prof. Odesa nat. polytechnic univ. Denisova A.E. 